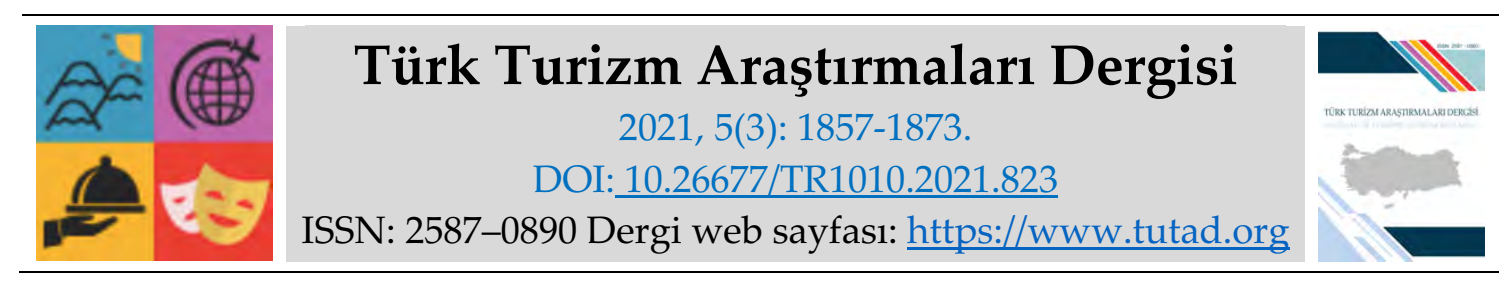

ARASTIRMA MAKALESI

\title{
Sokak Lezzetleri Konusuyla İlgili Yapılan Çalışmaların Bibliyometrik Analizi
}

Dr. Öğr. Üyesi Şaban KARGİGLIOĞLU, Muğla Sıtkı Koçman Üniversitesi, Turizm Fakültesi, Muğla, e-posta: sabankargiglioglu@mu.edu.tr ORCID: https://orcid.org/0000-0002-8952-7225

Öz

Sokak lezzetleri, son yıllarda Türkiye'de ve Dünya'da turistik çekicilik unsuru olarak ön plana çıkmıştır. Bu konu ile ilgili yapılan akademik çalışmalarda artmakta olduğu görülmektedir. Mevcut çalışma ile Türkiye'de sokak lezzetleri konusuyla ilgili olarak ilk yayının yapıldığı 2016 yılından 2021 yılı Nisan ayına kadar yayınlanan makaleler ve lisansüstü tezlerin bibliyometrik olarak analizi amaçlanmıştır. Bu kapsamda Yükseköğretim Kurulu Başkanlığı'nın Ulusal Tez Merkezi resmi internet adresinde kayıtlı olan lisansüstü tezler, Google Akademik, ULAKBİM veri tabanlarında yer alan, sokak lezzetleri ve sokak yemekleri anahtar kelimelerinin birlikte yer aldığı ulusal ölçekte yayınlanmış makaleler ve tezlerin, yayınlandıkları yıllar, türleri, enstitü, üniversite, ana bilim dalları, konu ve veri toplama yöntemleri açısından bibliyometrik analiz ile incelenmiştir. Yapılan araştırmalar sonucunda, 25 makale ve 8 tez tespit edilmiştir. Sonuç olarak sokak lezzetleri ile ilgili yapılan çalışmalarının 2019 yılı itibariyle sayı olarak artış gösterdiği; gıda güvenliği, şehirlerin sokak lezzetlerinin envanteri, tüketici tercihleri, destinasyon tercihi ve imajı, festivallerin incelendiği görülmektedir.

Anahtar Kelimeler: Sokak Lezzetleri, Sokak Yemekleri, Turizm Araştırmaları, Gastronomi, Bibliyometrik Analiz.

Makale Gönderme Tarihi: 12.05 .2021

Makale Kabul Tarihi: 03.09.2021

\section{Önerilen Atıf:}

Kargiglioğlu, Ş. (2021). Sokak Lezzetleri Konusuyla İlgili Yapılan Çalışmaların Bibliyometrik Analizi, Türk Turizm Araştırmaları Dergisi, 5(3): 1857-1873.

(C) 2021 Türk Turizm Araştırmaları Dergisi. 


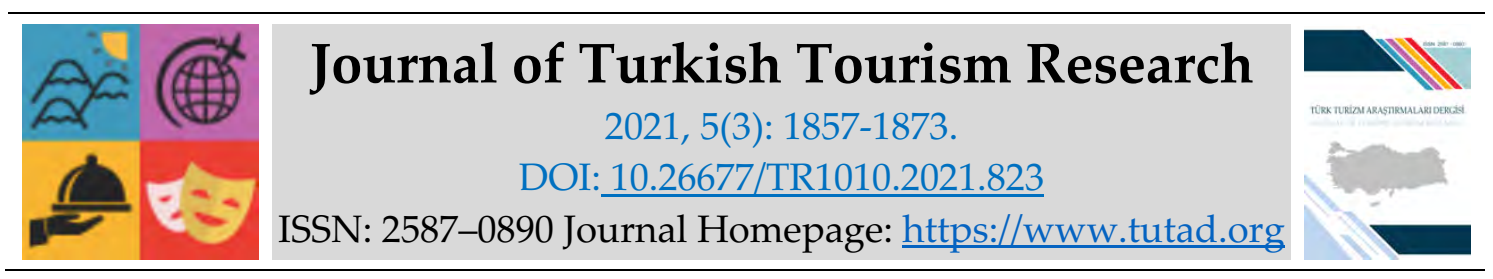

\title{
$\underline{\text { RESEARCH PAPER }}$
}

\author{
Bibliometric Analysis of Studies on the Subject of Street Food
}

Assistant Prof. Dr. Şaban KARGİGLİĞLUU, Muğla Sıtkı Koçman University, Faculty of Tourism, Muğla, e-mail: sabankargiglioglu@mu.edu.tr

ORCID: https://orcid.org/0000-0002-8952-7225

\begin{abstract}
Street foods have come to the fore as an element of tourist attraction in Turkey and the world in recent years. It is seen that there is an increase in academic studies on this subject. With this study, it is aimed to analyze the articles and postgraduate theses on the subject of street food published from 2016 until April 2021 in Turkey bibliometrically. In this context, the years of publication, types, institute, university, departments, subject and data collection methods of the postgraduate theses registered on the official website of the National Thesis Center of the Council of Higher Education, the nationally published articles and theses on the Google Scholar and Turkish Academic Network and Information Center (ULAKBIM) databases which have street food and street delicacies in the keywords were examined by bibliometric analysis. 25 articles and 8 theses were determined from the research. As a result, the number of studies on street flavors increased as of 2019; It is seen that the topic of food safety, the inventory of the street foods of the cities, consumer preferences, destination preference and image, and festivals are examined.
\end{abstract}

Keywords: Street Flavour, Street Food, Tourism Research, Gastronomy, Bibliometric Analysis. Received: 12.05 .2021

Accepted: 03.09.2021

\section{Suggested Citation:}

Kargiglioğlu, Ş. (2021). Bibliometric Analysis of Studies on the Subject of Street Food, Journal of Turkish Tourism Research, 5(3): 1857-1873.

(C) 2021 Türk Turizm Araştırmaları Dergisi. 


\section{Gíriş}

Sokak lezzetleri, bir ülkenin mutfak kültürüne en kolay erişilebilecek gastronomik ürünlerdir. Ayrıca her gelir grubundan turiste hitap eden sokak lezzetlerinin sokakta satışı yapılması bu ürünleri değersiz kılar düşüncesine belki de bir karşılık olarak Michelin yıldızlı sokak lezzetleri satıcıları dahi bulunmakta olduğu bilinmektedir. Ayrıca sokak lezzetlerinin yerel halk ve turistler tarafından rağbet görmesiyle birlikte yiyecek içecek işletmelerinin menülerinde bu yiyecek ve içeceklerin yer almaya başladığı göze çarpmaktadır. Bununla birlikte sokak lezzetleriyle alakalı olarak akademik çalışmalarda bir artış yaşandığı, gastronomide trendler ders içeriğinde sokak lezzetlerinin işlendiği görülmektedir.

Solunoğlu ve Nazik (2018)'in yaptıkları çalışmada, sokak lezzetlerinin ülkelerin yerel mutfak kültürlerini temsil ettiğinden ve de kullanılan ürünler yerel, mevsimindeki taze malzemelerden oluşan ve direkt üreticiden temin edilmektedir (Solunoğlu ve Nazik, 2018). Osmanlıdan günümüze kültürel miras olarak kalan sokak lezzetleri tüketimi Türk yemek kültürünün vazgeçilmez bir öğesi haline gelmiştir. Sanayi devrimiyle birlikte dışarıda yeme-içme faaliyetlerinin artmaya başladığından bu yana gerek ekonomik gerekse zaman açısından sokak yemekleri ön plana çıkmaktadır. Sokak yemeklerinin sosyal boyutuyla değerlendirildiğinde, sokak gıda satışının yapıldığı yerler buluşma noktası işlevi görmektedir (Özden, 2015).

Kargiglioğlu ve Aksoy'un (2019) yaptıkları çalışma; Sokak lezzetleri konusuyla ilgili yapılmış çalışmalarda daha çok gıda güvenliği ilişkisinin incelendiği görülmüştür. Son dönemde yayınlanmış çalışmalarda ise, destinasyon seçimi, soka gıda satıcıları, tüketici tutumları, gastronomi turizmi, gastronomik ürün gibi konularla ilişkilendirilmiş çalışmaların yapıldığı görülmektedir (Kargiglioğlu ve Aksoy, 2019).

Gastronomi ve mutfak sanatları alanında sokak lezzetleri konusu ile ilgili son birkaç yılda çalışmaların arttığı gözlemlenmektedir. Bu noktadan hareketle sokak lezzetleri ile ilgili yazılmış olan makalelerin ve lisansüstü tezlerin incelenmesi, kavramın hangi yönleriyle araştıııldığı ve bu araştırmaların ne sonuca ulaştığını görmek açısından önem taşımaktadır. Çalışmada sadece Türkçe yazılmış olan makale ve lisansüstü tezler değerlendirilmiştir. Yapılacak olan çalışmalara rehberlik etmek üzere şimdiye kadar yapılmış olan çalışmalar sunulmuştur.

\section{SOKAK LEZZETLERI}

Sokak lezzetleri kavramının tanımı, 1986 yılında, Gıda ve Tarım Örgütü (Food and Agricultural Organization, FAO, 1986) tarafından Endonezya' nın Jakarta kentinde gerçekleştirilen "Asya' daki Sokak Yemekleri Bölgesel Çalıştayı"nda yapılmıştır. Tanımlamaya göre; özellikle cadde, sokak ya da halka açık mekanlarda seyyar olarak veya belli bir noktada hizmet veren eşzamanlı olarak sokak gıda satıcıları tarafından hazırlanan ve/veya tüketime hazır yiyecek ve içecek olarak açiklanmıştır (Food and Agriculture Organization of the United Nations (FAO), 1986). Dünya Sağlık Örgütü (WHO)'nün tanımına göre sokak yemekleri “Sokak gıda satıcılarınca sokaklarda veya halkın ortak kullanımındaki kamu alanlarında satılan ve tüketiciler tarafından herhangi bir işlem yapmadan o an ya da kısa süre içerisinde tüketilen yiyecek ve içecekler" şeklinde ifade edilmiştir (WHO, 1996: 6).

Sokak yiyecekleri farklı coğrafyalarda farklı şekillerde tüketilmekte ve çoğu durumda yerel ürün ve pişirme teknikleriyle hazırlandığ 1 için de tüketildiği toplumun özelliklerini yansıtabilmektedir. Aynı zamanda eğlenceli ve pratik bir tüketim olanağı sunabilen sokak yiyecekleri gastronomik bir ürün olma ve turizmin çeşitlenmesi için pazarlanabilme potansiyeline sahiptir (Kurt, 2018: 11). 
Sokak lezzetleri, kentte ve kırsalda bulunan düşük gelir grubundaki kişiler için ucuz, besleyici bir besin kaynağı, turistler için ekonomik açıdan avantajlı, çekici ve çeşitli yiyecek kaynağı olma özelliği taşımaktadır. Özellikle kadınlar için önemli bir gelir kaynağı ve serbest meslek sahibi olma şansı, düşük sermaye yatırımıyla iş becerileri geliştirme fırsatı sunmaktadır (Kargiglioğlu, 2019).

Geçmişte yüksek gelir grubunun tercih etmediği sokak lezzetleri ile ilgili olarak günümüze gelindiğinde birinci sınıf restoranların menülerinde dahi sokak lezzetlerinin görüldüğü gözlemlenmektedir (Kargiglioğlu, 2019). Sokak gıdalarının özellikle kadınlar için istihdam potansiyeli açısından, düşük ve orta gelir grubundaki tüketicilerin uygun fiyatlarla beslenme ihtiyaçlarına hizmet etmesi açısından önemli bir sosyo-ekonomik rol oynadığı kabul edilmektedir. Dünyanın birçok büyük şehrinde milyonlarca dolar eşdeğerinin, sokak gıdalarının satışıyla her geçen gün değiştiği tahmin edilmektedir (Kargiglioğlu, 2019).

Osmanlıdan günümüze kadar gelen süreçte sokak lezzetlerinin rolü yadsınamaz bir şekilde karşımıza çıkmaktadır. Özellikle hem Türk kökenli vatandaşların hem de gayrimüslimlerin sokak lezzetleri satıcılığı yaptığı, sokak lezzetleri satışının olduğu yerlerde sosyal ilişkilerin kurulduğu bilinmektedir. Günümüzde sokak lezzetlerinin, turistik ürün olarak kullanılması pek çok ülkede görülmektedir.

Geçmişte iş bulamayan kişilerin, düşük bütçe ile gerçekleştirdiği sokak lezzetleri satıcılığ 1 günümüzde çoğu gelişmekte olan ülkede değişim göstermeye başlamıştır. Günümüzün yeni sokak lezzetleri satıcıları ise sınırlı iş alternatiflerine sahip bireyler, iş bulmakta zorlanan nitelikli yeni mezunlar ya da kriz nedeniyle önceki işlerde küçülmeye uğrayanlar, işsiz kalan profesyonellerdir (Bhowmik, 2005).

Sokak lezzetleri, mutfak kültürünün önemli bir temsilcisi olarak görülmektedir. Turistik çekicilik unsuru olarak uzun zamandır Uzak Doğu ülkelerinde oldukça popüler olan sokak lezzetleri son zamanlarda ülkemizde de artan taleple birlikte turistik çekicilik unsuru olarak kullanılabilecek gastronomik bir ürün olarak karşımıza çıkmaktadır. Ancak, sokak lezzetlerinin bir çekim aracı olarak kullanılması ve geliştirilmesi için, turistlerin sokak lezzetlerine karşı satın alma davranışları, sokak lezzetleri satıcılarına yönelik gıda güvenliği eğitimlerinin verilmesi ve sokak lezzetleri satış noktalarının turistik haritalarda işaretlenmesi gibi uygulamalara geçmek önemlidir.

Sokak lezzetlerini sunmak için zamanda ve mekânda kısıtlı kalmadan, tüketicinin olabileceği her yere ulaşabilmek adına dükkan veya restoran tarzında bir satış yerine pek ihtiyaç duyulmamaktadır (Leong vd., 2010). Son yıllarda alışveriş merkezlerinin belli katlarında sokak lezzetleri ile ilgili stantların kurulması, bazı şehirlerde sokak lezzetleri festivallerinin düzenlenmesi yine aynı şekilde geçmişten günümüze gelen maç günlerinde statların dışında ve konser günlerinde konser salonlarının dışında sokak lezzetleri satıcıları işlerini yerine getirmektedir.

\section{YÖNTEM}

$\mathrm{Bu}$ araştırmanın amacı sokak lezzetleri/sokak yemekleri üzerine yazılmış yüksek lisans ve doktora tezleri ile Google Akademikte erişilen Türkçe çalışmaların bibliyometrik açıdan incelenmesidir. Araştırmanın evrenini, 2021 yılına kadar yayımlanan başlı̆̆ında sokak yemekleri ve sokak lezzetleri kelime grubu bulunan makale ve tezler oluşturmaktadır. Tarama ile ilgili herhangi bir süre kısıtlılığı konulmamıştır. Çalışmada, araştırmanın yapıldığı tarihe kadar Yükseköğretim Kurulu Başkanlığı'nın Ulusal Tez Merkezi resmi internet sitesinde kayıtlı olan yüksek lisans ve doktora tezleri ile Google Akademik veri tabanında yer alan makaleler 
taranmıştır. Tarama sırasında "Sokak Lezzetleri" ve "Sokak Yemekleri" anahtar kelimeleri yer almıştır. Bu kapsamda toplam 25 makale, 8 tez değerlendirilmiştir. Çalışmada nitel araştırma yöntemi kullanılmış olup, doküman-arşiv tarama tekniği kullanılmıştır. Verilerin analizinde ise betimsel analiz ve içerik analizi yöntemi kullanılmıştır. Çalışmaların yayınlandığı yıl, türü, amacı, veri toplama yöntemi, analizi ve sonuçları açısından incelenmiştir.

Tablo 1. Çalışma Kapsamına Dahil Edilen Lisansüstü Tezler

\begin{tabular}{|c|c|c|c|c|c|}
\hline $\begin{array}{l}\text { Çalış } \\
\text { ma }\end{array}$ & Tür & Amaci & $\begin{array}{c}\text { Veri } \\
\text { Toplama } \\
\text { Araci }\end{array}$ & Analizler & Sonuçlar \\
\hline 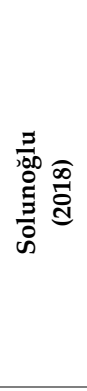 & $\mathrm{DR}$ & $\begin{array}{l}\text { Planlı davranış teorisi } \\
\text { kapsamında } r \text { sokak } \\
\text { lezzeti kapsamında } \\
\text { ele } r \text { alınarak } \\
\text { davranıssal niyet } \\
\text { üzerindeki etkisini } \\
\text { belirlemek }\end{array}$ & Anket & $\begin{array}{l}\text { T testi, } \\
\text { ANOVA }\end{array}$ & $\begin{array}{l}\text { Katılımcıların sokak lezzetlerini tüketmekle ilgili bir } \\
\text { sağlık sorunu olmadığı, aylık } 1 \text { ile } 5 \text { defa arasında } \\
\text { sokak lezzetleri tükettikleri, buna ilişkin ortalama 51- } \\
100 \text { Đ arası harcama yaptıkları, yemek kalitesi } \\
\text { açısından sokak lezzetlerini tüketmenin kolay } \\
\text { olduğunu ve görsel açıdan çekici ve otantik buldukları } \\
\text { ve yerel kültürü temsil ettiğine inandıklarını, sokak } \\
\text { lezzetlerini düşünmenin kendilerini mutlu ettiğini } \\
\text { ifade etmişlerdir. Hijyen tutumu açısından } \\
\text { katılımcıların sokak lezzetlerini tüketmekten } \\
\text { çekinmedikleri ortaya çıkmıştır. }\end{array}$ \\
\hline 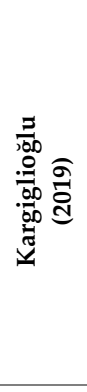 & DR & $\begin{array}{lr}\text { Sokak lezzetlerine } \\
\text { yönelik } \\
\text { davranış } \\
\text { bağlamında } \\
\text { İstanbul'u teorisi } \\
\text { eden turistlerin tekrar } \\
\text { ziyaret niyeti ile } \\
\text { destinasyon seçimine } \\
\text { yönelik davranışsal } \\
\text { niyet üzerindeki } \\
\text { etkisini belirlemek }\end{array}$ & Anket & $\begin{array}{c}\text { T testi, } \\
\text { ANOVA, } \\
\text { Regresyon }\end{array}$ & $\begin{array}{l}\text { Davranışa yönelik tutum ve öznel normun hem tekrar } \\
\text { ziyaret etme niyetine hem de destinasyon seçimine } \\
\text { yönelik davranışsal niyete olumlu etkisi olduğu } \\
\text { görülmektedir. Algılanan davranışsal kontrol ile ilgili } \\
\text { olarak ise, tekrar ziyaret etme niyetine ve destinasyon } \\
\text { seçimine yönelik davranışal niyete herhangi bir } \\
\text { etkisinin olmadığ görülmektedir. }\end{array}$ \\
\hline 商 & YL & $\begin{array}{l}\text { Tüketicilerin } \\
\text { algıladıkları hazal, } \\
\text { faydacı değerler ile } \\
\text { memnuniyetleri ve } \\
\text { davranışsal niyetleri } \\
\text { arasındaki ilişkiyi } \\
\text { açıklamak }\end{array}$ & Anket & $\begin{array}{c}\text { Faktör } \\
\text { analizi, } \\
\text { Korelasyon } \\
\text { Regresyon }\end{array}$ & $\begin{array}{l}\text { Algılanan hazsal ve faydacı değer, tüketici } \\
\text { memnuniyetini } \\
\text { memnuniyetinin de davranışsal niyet üzerinde etkili } \\
\text { olduğu görülmektedir. Ayrıca algılanan hazsal } \\
\text { değerin, tüketici memnuniyeti üzerinde faydacı } \\
\text { değerden daha etkili olduğu saptanmıştır. }\end{array}$ \\
\hline 范 & YL & $\begin{array}{l}\text { Destinasyon } \\
\text { tanıtımında ve insan } \\
\text { hayatında önemli bir } \\
\text { unsur olan sokak } \\
\text { lezzetlerinin Türk } \\
\text { yazılı medyasındaki } \\
\text { (ulusal gazete ve } \\
\text { ekleri) yansıması, } \\
\text { haberlerin teknik ve } \\
\text { gastronomik anlamda } \\
\text { ne şekilde ele } \\
\text { alındığını incelenmek }\end{array}$ & $\begin{array}{c}\text { Arşiv- } \\
\text { Doküma } \\
\text { n Tarama }\end{array}$ & $\begin{array}{l}\text { İçerik } \\
\text { analizi }\end{array}$ & $\begin{array}{l}\text { Sokak lezzetlerinin daha çok ulusal gazete eklerinde ve } \\
\text { hafta sonu yayınlandığı, ilk sayfalarda yer almadığı ve } \\
\text { ana tema olarak işlenmediği görülmüştür. Sokak } \\
\text { lezzetleriyle ilgili etkinliklerin haber sayısına etki ettiği } \\
\text { ancak sokak lezzetleriyle ilgili haberlerin sistematik bir } \\
\text { işlenişinin olmadığı sonucuna ulaşılmıştır. }\end{array}$ \\
\hline 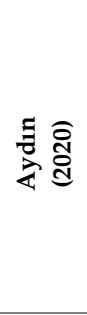 & YL & $\begin{array}{l}\text { Sokak lezzetlerinin } \\
\text { tüketiminden } \\
\text { kaynaklanabilecek } \\
\text { g1da güvenliği riskleri } \\
\text { değerlendirilmek }\end{array}$ & $\begin{array}{c}\text { Anket- } \\
\text { Laboratu } \\
\text { var }\end{array}$ & $\begin{array}{l}\text { Mikrobiyol } \\
\text { ojik analiz }\end{array}$ & $\begin{array}{l}\text { Analiz için alınan } 20 \text { adet yiyecek numunesinin } 13 \\
\text { adetinde (\%65) S.aureus (Staphylococcus aureus), } 19 \\
\text { adetinde (\%95) TMAB (Toplam mezofilik aerobik } \\
\text { bakteriler), } 5 \text { adetinde (\%25) E. coli (Escherichia coli), } 2 \\
\text { adetinde (\%10) Salmonella spp. ve } 14 \text { adetinde (\% 70) } \\
\text { B. cereus (Bacillius cereus) tespit edilmiştir Sokak } \\
\text { lezzetlerinin gıda güvenliği açısından risk oluşturduğu } \\
\text { ve ana kaynağının satıcılar ve satış alanı çevresi olduğu } \\
\text { düşünülmektedir. }\end{array}$ \\
\hline
\end{tabular}




\begin{tabular}{|c|c|c|c|c|c|}
\hline 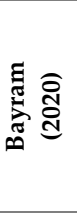 & YL & $\begin{array}{l}\text { Antalya'da sunulan } \\
\text { sokak lezzetlerine } \\
\text { yönelik tüketicilerin } \\
\text { zihinlerindeki } \\
\text { gastronomik imaj ve } \\
\text { tutumları incelemek }\end{array}$ & Anket & $\begin{array}{l}\text { Frekans } \\
\text { analizi, } \\
\text { ANOVA }\end{array}$ & $\begin{array}{l}\text { Sokak lezzetlerinin katılımcıların en çok arkadaşlarla } \\
\text { beraberken veya yalnızken tercih edildiği, sokak } \\
\text { lezzetlerine yönelik tutumun, gastronomik imaj } \\
\text { algısının ve satın alma niyetinin çeşitli demografik } \\
\text { değişkenler açısından farklılıklar gösterdiği sonucu } \\
\text { ortaya konulmuştur. }\end{array}$ \\
\hline 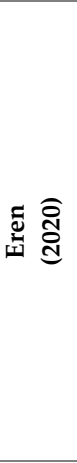 & YL & $\begin{array}{lr}\text { Sokak } & \text { lezzetleri } \\
\text { girişimcilerinin } \\
\text { yaşamış } & \text { oldukları } \\
\text { deneyimler, } & \\
\text { işletmelerinin } & \text { mevcut } \\
\text { durumu, formal ve } \\
\text { informal } & \text { eğitim } \\
\text { düzeyleri } & \text { ve } \\
\text { düzenlenecek } & \text { olan } \\
\text { eğitimlere } & \text { katılım } \\
\text { istekleri hakkındaki } \\
\text { görüşleri } & \text { ortaya } \\
\text { koymak } & \end{array}$ & $\begin{array}{l}\text { Yarı } \\
\text { yapılandı } \\
\text { rılmış } \\
\text { görüşme }\end{array}$ & $\begin{array}{c}\text { Betimsel } \\
\text { analiz }\end{array}$ & $\begin{array}{l}\text { Girişimcileri yatırıma çeken en önemli unsur, sokak } \\
\text { lezzetlerini aile geleneği olarak görmeleri olmuştur. } \\
\text { Girişimcilerin yoğun çalışma saatleri sebebiyle formal } \\
\text { eğitime yeteri kadar önem vermedikleri, informal } \\
\text { eğitimin sokak lezzetlerinde daha etkili bir öğrenme } \\
\text { biçimi olduğunu belirttikleri görülmektedir. }\end{array}$ \\
\hline 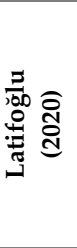 & YL & $\begin{array}{l}\text { İstanbul'da "Sokak } \\
\text { yemeklerinin } \\
\text { bilinirlik, beğeni, } \\
\text { gastronomik } \\
\text { hareketlilik ve gida } \\
\text { güvenliği yönünden } \\
\text { incelemek }\end{array}$ & Anket & $\begin{array}{c}\text { Faktör } \\
\text { analizi, } \\
\text { Korelasyon }\end{array}$ & $\begin{array}{l}\text { Sokak yemeklerinin bilinirlik ve beğenilme } \\
\text { düzeylerinin yüksek olduğu, sokak yemeklerinin } \\
\text { gastronomik hareketliliği az da olsa etkilediği, gıda } \\
\text { güvenliğinin ise katılımcılar için çok önemli olmadığ1 } \\
\text { sonucuna ulaşılmıştır. }\end{array}$ \\
\hline
\end{tabular}

Tablo 2. Çalışma Kapsamına Dahil Edilen Makaleler

\begin{tabular}{|c|c|c|c|c|}
\hline Çalışma & $\begin{array}{l}\text { Dergi } \\
\text { Adı }\end{array}$ & Amacı & Analizler & Sonuçlar \\
\hline 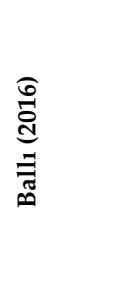 & $\begin{array}{c}\text { Journal } \\
\text { of } \\
\text { Touris } \\
\text { m and } \\
\text { Gastro } \\
\text { nomy } \\
\text { Studies }\end{array}$ & $\begin{array}{lr}\text { Gastronomi } & \text { turizmi } \\
\text { açısından } & \text { sokak } \\
\text { yemeklerini } & \\
\text { değerlendirmek } & \text { ve } \\
\text { Adana İlinin } & \text { sahip } \\
\text { olduğu } & \text { sokak } \\
\text { yemeklerini } & \\
\text { incelemek. }\end{array}$ & $\begin{array}{l}\text { İçerik } \\
\text { analizi }\end{array}$ & $\begin{array}{l}\text { Adana, kendine özgü yemekleri ile, gastronomi } \\
\text { turizminden yararlanılarak ön plana çıartılmalı ve bu } \\
\text { sayede destinasyon imajının arttırılarak gastronomi } \\
\text { turizminin bölgeye olumlu etki yaratması sağlanabilir. } \\
\text { Öncelikle Adana'da bu turizm türünü geliştirmek amacıla } \\
\text { bölgeye özgü yemeklerin hazırlanmasından sunumuna } \\
\text { kadar geçen sürede azami ölçüde gıda güvenliği ne dikkat } \\
\text { edilmesi gerekmektedir. }\end{array}$ \\
\hline 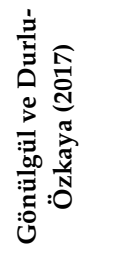 & $\begin{array}{c}\text { Journal } \\
\text { of } \\
\text { Touris } \\
\text { m and } \\
\text { Gastro } \\
\text { nomy } \\
\text { Studies }\end{array}$ & $\begin{array}{l}\text { Toronto ve Los } \\
\text { Angeles'da satilan } \\
\text { sokak lezzetlerini } \\
\text { incelenmesi }\end{array}$ & $\begin{array}{l}\text { Görüşme } \\
\text { ve Gözlem }\end{array}$ & $\begin{array}{l}\text { Los Angeles ve Toronto satışı yapılan sokak yemeklerinin } \\
\text { çoğunluğunu fast food tarzı yiyecekler oluşturmaktadır. } \\
\text { Ancak, satış yapılan konuma göre menü içeriklerinde, araç } \\
\text { gereçlerde ve servis şeklinde farklılıklar olduğu } \\
\text { gözlemlenmiştir. }\end{array}$ \\
\hline 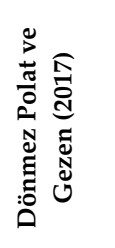 & $\begin{array}{c}\text { Journal } \\
\text { of } \\
\text { Touris } \\
\text { m and } \\
\text { Gastro } \\
\text { nomy } \\
\text { Studies }\end{array}$ & $\begin{array}{l}\text { Sokak lezzetleri } \\
\text { satıcılarının turizm ve } \\
\text { gastronomideki } \\
\text { önemine dikkat } \\
\text { çekmek }\end{array}$ & $\begin{array}{l}\text { İçerik } \\
\text { analizi }\end{array}$ & $\begin{array}{l}\text { Sokak lezzetleri satıcıları hakkında farkındalık yaratmak } \\
\text { adına büyük önem taşımakta olduğu düşünülmektedir. }\end{array}$ \\
\hline
\end{tabular}




\begin{tabular}{|c|c|c|c|c|c|}
\hline 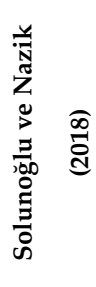 & & $\begin{array}{l}\text { Journal } \\
\text { of } \\
\text { Touris } \\
\text { m and } \\
\text { Gastro } \\
\text { nomy } \\
\text { Studies }\end{array}$ & $\begin{array}{l}\text { Gaziantep } \\
\text { lezzetlerine yönelik } \\
\text { tüketici tercihlerini } \\
\text { tespit } \\
\text { demografik açıdan ve } \\
\text { çeşitli değişkenlerle } \\
\text { farklılıkların ortaya } \\
\text { konması }\end{array}$ & $\begin{array}{l}\text { t testi, } \\
\text { ANOVA } \\
\text { ve Post-hoc } \\
\text { testi }\end{array}$ & $\begin{array}{l}\text { Çalışma ile ilgili sonuçlara bakıldığında, sokak } \\
\text { yemeklerine ilişkin tüketici tercihlerinin genelinin olumlu } \\
\text { olduğu, Eğitim-gelir ve mesleklere göre farklılıklar } \\
\text { olmasına karşı cinsiyetle ilgili tercihlerde farklılık } \\
\text { bulunmamakta olduğu sonucuna ulaşılmıştır. }\end{array}$ \\
\hline 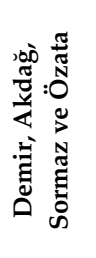 & 文 & $\begin{array}{l}\text { Güncel } \\
\text { Turiz } \\
\text { m } \\
\text { Araştır } \\
\text { maları } \\
\text { Dergisi }\end{array}$ & $\begin{array}{l}\text { Sokak lezzetlerini, } \\
\text { Türkiye'nin en fazla } \\
\text { nüfusa sahip şehri } \\
\text { İstanbul ilinde } \\
\text { gastronomik bir değer } \\
\text { olarak araştırmak }\end{array}$ & - & $\begin{array}{l}\text { İstanbul'da yürütülen bu çalışmada sokak lezzetlerine } \\
\text { talebin oldukça yüksek olduğu, farklı bölgelerde farklı } \\
\text { özelliklerde olduğu sonucuna varılmış ve sokak gıda } \\
\text { satıcılarının bu işi amatör olarak yürüttüğü } \\
\text { gözlemlenmiştir. İstanbul'da satışa sunulan sokak } \\
\text { lezzetlerinin çeşitliliğine bakıldığında, bunda en büyük } \\
\text { etkinin kırsaldan İstanbul'a olan göçle ilişkilendirebiliriz. }\end{array}$ \\
\hline 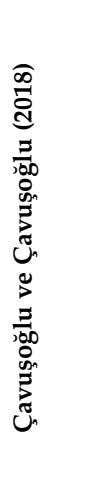 & & $\begin{array}{l}\text { Güncel } \\
\text { Turiz } \\
\text { m } \\
\text { Araştır } \\
\text { maları } \\
\text { Dergisi }\end{array}$ & 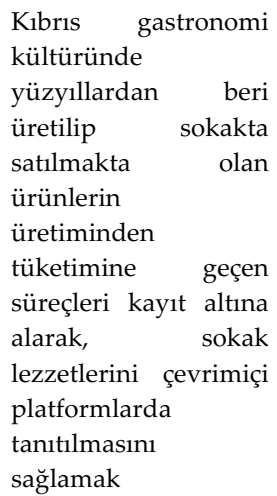 & - & $\begin{array}{l}\text { Araştırmanın sonuçları arasında, } \\
\text { "www.kibrissokaklezzetleri.com" web site projenin hayata } \\
\text { geçirilmesi ve sokak lezzeti satıcılarının teşvik edilmesi yer } \\
\text { almaktadır. }\end{array}$ \\
\hline 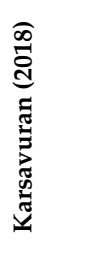 & & $\begin{array}{l}\text { Journal } \\
\text { of } \\
\text { Touris } \\
\text { m and } \\
\text { Gastro } \\
\text { nomy } \\
\text { Studies }\end{array}$ & $\begin{array}{l}\text { Sokak lezzetlerinin, } \\
\text { turizm ve gastronomi } \\
\text { alanında tartışmaya } \\
\text { açılması }\end{array}$ & $\begin{array}{c}\text { İçerik } \\
\text { analizi }\end{array}$ & $\begin{array}{l}\text { Sokak lezzetleriyle alakalı alanyazın tarandığından } \\
\text { çalışmaların gıda güvenliği ve sokak yemeklerinin } \\
\text { düzenlemesine dönük geliştiği halde, turizm ve } \\
\text { gastronomiyle ilişkilendirilen çalışma konusu oldukça } \\
\text { sınırlıdır. Sokak lezzetlerinin, gastronomi turizminin bir } \\
\text { ürünü olarak değerlendirilerek çalışmalar yapılması } \\
\text { önerisi sunulmuştur. }\end{array}$ \\
\hline 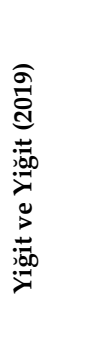 & & $\begin{array}{c}\text { TURA } \\
\text { N- } \\
\text { SAM } \\
\text { Ulusla } \\
\text { rarası } \\
\text { Bilimse } \\
1 \\
\text { Hakem } \\
\text { li } \\
\text { Dergisi }\end{array}$ & $\begin{array}{l}\text { Sokak lezzetlerinin } \\
\text { gastronomik ürün } \\
\text { olarak ele alınması } \\
\text { amaçlanmaktadır. }\end{array}$ & - & $\begin{array}{l}\text { Sokak lezzetlerine tüketici tercih nedenleri açısından } \\
\text { bakıldığında maliyetinin ve satış fiyatının oldukça cazip } \\
\text { olduğu ve bu yüzden gelişmekte olan ülkelerde daha fazla } \\
\text { tercih edildiği öne sürülmektedir. Sokak lezzetleri } \\
\text { konusunda Türkiye'ye bakıldığında ise bu anlamda } \\
\text { festivallerin düzenlendiği görülmektedir. }\end{array}$ \\
\hline  & & $\begin{array}{c}\text { Manas } \\
\text { Sosyal } \\
\text { Araştır } \\
\text { malar } \\
\text { Dergisi }\end{array}$ & $\begin{array}{l}\text { Sokak lezzetlerinin } \\
\text { tercihinde } \\
\text { tüketicilerin sokak } \\
\text { gida satıcılarına olan } \\
\text { güveni ile algılanan } \\
\text { risk ve fayda } \\
\text { üzerindeki etkisi, } \\
\text { algılanan risk ve } \\
\text { faydanın ise tutum ve } \\
\text { satın alma davranış } \\
\text { üzerindeki etkilerini } \\
\text { araştırmak }\end{array}$ & $\begin{array}{l}\text { T testi ve } \\
\text { Yapısal } \\
\text { Eşitlik } \\
\text { Modelleme } \\
\text { si }\end{array}$ & $\begin{array}{l}\text { Sokak gıda satıcısına olan güvenin algılanan fayda } \\
\text { üzerinde olumlu etkisinin olduğu, algılanan riskin tutum } \\
\text { ve davranışsal niyet üzerinde negatif anlamlı etkisi varken } \\
\text { algılanan faydanın ise bu iki değişken üzerinde pozitif } \\
\text { anlamlı bir etkisi tespit edilmiştir. }\end{array}$ \\
\hline
\end{tabular}




\begin{tabular}{|c|c|c|c|c|}
\hline 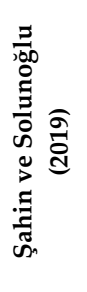 & $\begin{array}{l}\text { Journal } \\
\text { of } \\
\text { Travel } \\
\text { and } \\
\text { Hospit } \\
\text { ality } \\
\text { Manag } \\
\text { ement }\end{array}$ & $\begin{array}{l}\text { Tüketicilerin Mersin } \\
\text { sokak lezzetlerine } \\
\text { yönelik tutumlarının } \\
\text { ve tüketim niyetlerini } \\
\text { incelemek }\end{array}$ & $\begin{array}{l}\text { Yapısal } \\
\text { Eşitlik } \\
\text { Modelleme } \\
\text { si ve Faktör } \\
\text { analizi }\end{array}$ & $\begin{array}{l}\text { Sokak lezzetleri tüketiminde çevresel faktörlerin de etkili } \\
\text { olduğu görülmüştür. Gida güvenliği ile ilgili ise sokak } \\
\text { lezzetleri tüketicilerinin kaygı düzeylerini etkilediği } \\
\text { saptanmıştır. }\end{array}$ \\
\hline 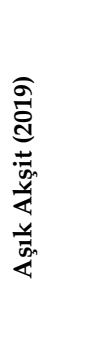 & $\begin{array}{c}\text { Ulusla } \\
\text { rarası } \\
\text { Türk } \\
\text { Dünya } \\
\text { sı } \\
\text { Turiz } \\
\text { m } \\
\text { Araştır } \\
\text { maları } \\
\text { Dergisi }\end{array}$ & $\begin{array}{l}\text { Turistlerin sokak } \\
\text { yiyeceklerine yönelik } \\
\text { tutumlarinın } \\
\text { belirlenmesi }\end{array}$ & $\begin{array}{c}\mathrm{T} \text { testi ve } \\
\text { Anova }\end{array}$ & $\begin{array}{l}\text { Sokak lezzetlerine karşı tutumun genel olarak olumlu } \\
\text { olduğu ortaya konulmuştur. Tutuma yönelik } \\
\text { ortalamalarda en yüksek oran hizmet kalitesi için en düşük } \\
\text { oran ise hijyenle alakalıdır. }\end{array}$ \\
\hline 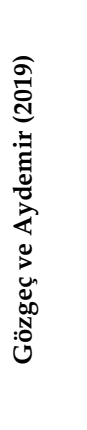 & $\begin{array}{l}\text { Manas } \\
\text { Sosyal } \\
\text { Araştır } \\
\text { malar } \\
\text { Dergisi }\end{array}$ & $\begin{array}{l}\text { Kadın sokak gıda } \\
\text { satıcılarını bu girişime } \\
\text { iten sebepleri, } \\
\text { sattıkları gıdaları, } \\
\text { satıcıların maddi- } \\
\text { manevi kazanımlarını } \\
\text { ortaya çıkarmak ve } \\
\text { yerel ölçekte } \\
\text { gastronomi } \\
\text { turizminin gelişimine } \\
\text { katkılarını } \\
\text { değerlendirmektir. }\end{array}$ & $\begin{array}{c}\text { Betimsel - } \\
\text { yorumlayıc } \\
1 \text { analiz }\end{array}$ & $\begin{array}{l}\text { Katılımcıların motivasyonlarında sosyal ve ekonomik } \\
\text { faktörlerin etkili olduğu ve sokak gıda satıcılı̆̆ından elde } \\
\text { edilen gelirin aile ekonomisini destekleyici özellikte } \\
\text { olduğu ortaya çıkmıştır. Bir diğer önemli sonuç ise ağızdan } \\
\text { ağıza pazarlamanın katılımcıların ürünlerini satmasında ve } \\
\text { ekstra iş almalarında önemli bir etken olduğudur. }\end{array}$ \\
\hline 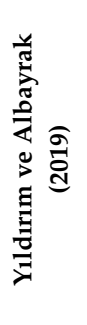 & $\begin{array}{c}\text { Journal } \\
\text { of } \\
\text { Touris } \\
\text { m and } \\
\text { Gastro } \\
\text { nomy } \\
\text { Studies }\end{array}$ & $\begin{array}{lr}\begin{array}{l}\text { Ülkemizde } \\
\text { turist }\end{array} & \text { en } \\
\text { şehirlerden } & \text { biri ça olan } \\
\text { İstanbul'u } & \text { ziyaret } \\
\text { eden } & \text { yabanc1 } \\
\text { turistlerin } & \text { İstanbul } \\
\text { sokak } & \text { lezzetleri } \\
\text { hakkında } & \text { görüşlerini } \\
\text { ortaya koymak }\end{array}$ & - & $\begin{array}{l}\text { Türkiye'ye gelen yabancı turistlerin genel olarak } \\
\text { İstanbul'da satılan sokak yemeklerinden memnun } \\
\text { oldukları ancak besin değeri ile temizlik, çalışanların } \\
\text { kıyafetleri ve satış yapılan mekanların temizliğinden } \\
\text { endişe duydukları saptanmıştır }\end{array}$ \\
\hline 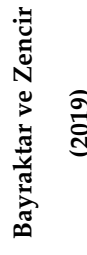 & $\begin{array}{c}\text { Journal } \\
\text { of } \\
\text { Touris } \\
\text { m and } \\
\text { Gastro } \\
\text { nomy } \\
\text { Studies }\end{array}$ & $\begin{array}{l}\text { Sokak lezzetleri } \\
\text { satıcılarının } \\
\text { meslekleri hakkındaki } \\
\text { görüşlerinin ortaya } \\
\text { koyulması }\end{array}$ & $\begin{array}{c}\text { Betimsel - } \\
\text { yorumlayıc } \\
1 \text { analiz }\end{array}$ & $\begin{array}{l}\text { Sokak lezzetleri satıcılığı mesleğini icra edenlerin çalışma } \\
\text { koşullarının zor ve ekonomik kaygı içinde oldukları } \\
\text { sonucuna ulaşılmıştır. Ayrıca, sokak lezzetleri satıcılarına } \\
\text { göre satmış oldukları ürünlerin gıda güvenliği açısından } \\
\text { hiçbir sakınca taşımadığını düşündüklerini belirtmişlerdir. }\end{array}$ \\
\hline 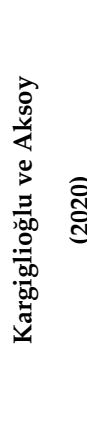 & $\begin{array}{l}\text { Journal } \\
\text { of } \\
\text { Hospit } \\
\text { ality } \\
\text { and } \\
\text { Touris } \\
\text { m } \\
\text { Issues }\end{array}$ & $\begin{array}{lr}\begin{array}{lr}\text { Sokak } \\
\text { yönelik }\end{array} & \text { lezzetlerine } \\
\text { davranış } & \text { planlı } \\
\text { bağlamında } & \text { teorisi } \\
\begin{array}{l}\text { İstanbul'u } \\
\text { eden }\end{array} & \text { ziyaret } \\
\text { destinasyon } & \text { turistlerin } \\
\text { yönelik } & \text { davrimine } \\
\text { niyet } & \text { üzerindeki } \\
\text { etkisini } & \text { belirlemek } \\
\text { amaciyla } & \\
\text { gerçekleştirilmiştir. }\end{array}$ & Regresyon & $\begin{array}{l}\text { Davranışa yönelik tutum ve öznel normun, destinasyon } \\
\text { seçimine yönelik davranışsal niyete olumlu etkisi olduğu } \\
\text { görülmektedir. Algılanan davranışsal kontrol ile ilgili } \\
\text { olarak ise destinasyon seçimine yönelik davranışsal niyete } \\
\text { herhangi bir etkisinin olmadığı̈ görülmektedir. }\end{array}$ \\
\hline
\end{tabular}




\begin{tabular}{|c|c|c|c|c|c|}
\hline 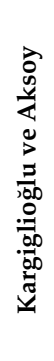 & ఫ్ర్ & $\begin{array}{c}\text { Journal } \\
\text { of } \\
\text { Hospit } \\
\text { ality } \\
\text { and } \\
\text { Touris } \\
\text { m } \\
\text { Issues }\end{array}$ & $\begin{array}{lr}\text { Sokak lezzetlerini } \\
\text { tatma amaciyla } \\
\text { İstanbul'a gelen } \\
\text { kişilerin demografik } \\
\text { bilgileri ile İstanbul'a } \\
\text { yapmış oldukları } \\
\text { seyahatlerden } \\
\text { memnuniyet } \\
\text { seviyelerini } \\
\text { belirlemek }\end{array}$ & $\begin{array}{l}\text { Frekans } \\
\text { analizi ve } \\
\text { Faktör } \\
\text { analizi }\end{array}$ & $\begin{array}{l}\text { Sokak lezzetlerini tatma amacıyla İstanbul'a gelen kişilerin } \\
\text { çoğunluğunun üniversite mezunu olduğu, seyahatlerinde } \\
\text { en çok tercih ettikleri ulaşım aracının uçak olduğu, İstanbul } \\
\text { seyahatlerindeki memnuniyet durumuna bakıldığında } \\
\text { büyük oranda memnuniyet duydukları sonucuna } \\
\text { ulaşılmışıtır. }\end{array}$ \\
\hline , & 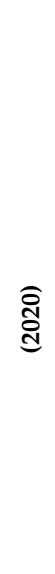 & $\begin{array}{c}\text { Artıbili } \\
\text { m } \\
\text { Adana } \\
\text { Alparsl } \\
\text { an } \\
\text { Türkeş } \\
\text { Bilim } \\
\text { ve } \\
\text { Teknol } \\
\text { oji } \\
\text { Üniver } \\
\text { sitesi } \\
\text { Sosyal } \\
\text { Bilimle } \\
\text { r } \\
\text { Dergisi }\end{array}$ & $\begin{array}{l}\text { Şehirlerin en temel } \\
\text { gastronomi öğesi ve } \\
\text { servisi olan sokak } \\
\text { lezzetlerinden } \\
\text { başlayıp, şehirlerdeki } \\
\text { en gelişmiş } \\
\text { gastronomi } \\
\text { servislerine } \\
\text { gastronomi } \\
\text { bölgelerinin ortaya } \\
\text { çıkışına kadar- kentsel } \\
\text { gelişim sürecinin } \\
\text { incelenmesidir. }\end{array}$ & - & $\begin{array}{l}\text { Adana'nın, gastronomik kaynak açısından zenginliğine } \\
\text { rağmen, hala bu kaynaklar turizme kazandırılamadığından } \\
\text { potansiyeli tam olarak değerlendirememiştir. Adana } \\
\text { mutfak kültürüne ait lezzetlerin, gastronomi turizmine } \\
\text { kazandırılarak yiyecek sokakları ve yeme içme alanlarının } \\
\text { bir an önce belirlenmesi gerekmektedir. }\end{array}$ \\
\hline 壹 & 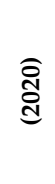 & $\begin{array}{l}\text { Food } \\
\text { and } \\
\text { Health }\end{array}$ & $\begin{array}{l}\text { Sokak lezzetlerinin } \\
\text { güvenlik ve hijyen } \\
\text { durumları ele almak }\end{array}$ & - & $\begin{array}{l}\text { Sokak lezzetlerinin üretim ve satış aşamalarındaki } \\
\text { eksiklikler bazı sorunlara yol açması normaldir. Sokak } \\
\text { lezzetleri satıcılarının sorunlarına yönelik yapılacaklar, } \\
\text { gıda güvenliği anlamında eğitimler ve çözüm önerileri } \\
\text { olmalıdır. }\end{array}$ \\
\hline  & 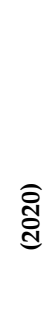 & $\begin{array}{c}\text { Kafkas } \\
\text { Üniver } \\
\text { sitesi } \\
\text { Sosyal } \\
\text { Bilimle } \\
\text { r } \\
\text { Enstitü } \\
\text { sü } \\
\text { Dergisi }\end{array}$ & $\begin{array}{l}\text { İzmir'i tatil amaciyla } \\
\text { tercih eden yerli } \\
\text { turistlerin, sokak } \\
\text { lezzetlerine ilişkin } \\
\text { değerlendirmelerini } \\
\text { belirlemek }\end{array}$ & $\begin{array}{l}\text { Faktör } \\
\text { analizi, T } \\
\text { testi ve } \\
\text { Anova }\end{array}$ & $\begin{array}{l}\text { İzmir'i tercih eden turistlerin, satılan sokak lezzetlerinde } \\
\text { kullanılan malzemelerin temiz, benzersiz lezzette } \\
\text { olduğunu belirtmişlerdir. Sokak lezzetlerini gelecekte de } \\
\text { tercih edeceklerini ve bu deneyimin kendilerini iyi } \\
\text { hissettirdiğinden bahsetmişlerdir. Ayrıca sokak lezzetleri } \\
\text { satıcılarını içten bulmuşlardır. }\end{array}$ \\
\hline$\frac{N}{\frac{N}{Z}}$ & 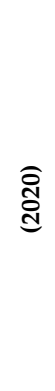 & $\begin{array}{l}\text { Akade } \\
\text { mik } \\
\text { Sosyal } \\
\text { Araştır } \\
\text { malar } \\
\text { Dergisi }\end{array}$ & $\begin{array}{l}\text { İzmir sokak } \\
\text { lezzetlerinin } \\
\text { gastronomik bir ürün } \\
\text { açısından incelenmesi } \\
\text { ve içeriği, tarihi, } \\
\text { yapılış şekli, satıldığı } \\
\text { yerler, ustaları, satan } \\
\text { kişiler/şsletmeler } \\
\text { bakımından } \\
\text { değerlendirilmesi } \\
\text { amaçlanmıştır. }\end{array}$ & $\begin{array}{l}\text { İçerik } \\
\text { analizi }\end{array}$ & $\begin{array}{l}\text { Boyoz, Sübye, Lokma Tatlısı, Kumru, Gevrek, Şambali, } \\
\text { Kokoreç, Buzlu Badem, Sulu Atom, Şerbet, Uykuluk ve } \\
\text { daha nice sokak lezzetlerinin İzmir'in Gastronomik ürünün } \\
\text { parçalarını oluşturduğu tespit edilmiştir. }\end{array}$ \\
\hline
\end{tabular}




\begin{tabular}{|c|c|c|c|c|}
\hline 萄 & $\begin{array}{c}\text { Journal } \\
\text { of } \\
\text { Touris } \\
\text { m } \\
\text { Resear } \\
\text { ch } \\
\text { Institut } \\
\text { e }\end{array}$ & $\begin{array}{l}\text { Gastronomi } \\
\text { turizminde, sokak } \\
\text { lezzetlerini } \\
\text { gastronomik bir ürün } \\
\text { olarak } \\
\text { değerlendirmek }\end{array}$ & $\begin{array}{c}\text { İçerik } \\
\text { analizi }\end{array}$ & $\begin{array}{l}\text { Sokak lezzetlerinin destinasyon seçiminde önemli } \\
\text { olduğunun buradan hareketle de sokak lezzetlerinin } \\
\text { gastronomik bir ürün olarak değerlendirilebileceğine } \\
\text { ulaşılmıştır. }\end{array}$ \\
\hline 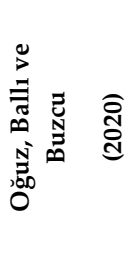 & $\begin{array}{l}\text { Turiz } \\
\text { m } \\
\text { Akade } \\
\text { mik } \\
\text { Dergisi }\end{array}$ & 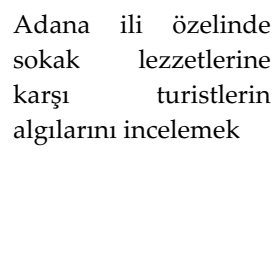 & $\begin{array}{l}\text { Faktör } \\
\text { analizi, T } \\
\text { testi, } \\
\text { Anova }\end{array}$ & $\begin{array}{l}\text { Sokak lezzetleri, bir bölgenin yemek kültürünü yansıtmada } \\
\text { önemli bir unsurdur. Sokak lezzetleri ucuz, erişilebilir, } \\
\text { lezzetli ve çok çeşitli olması nedeniyle destinasyonlar için } \\
\text { önemli bir kaynak oluşturmaktadır. Kamu kurum ve } \\
\text { kuruluşlarının sokak lezzetleri kaynaklarından } \\
\text { yararlanılması anlamında hizmet olanaklarını } \\
\text { geliştirmelidir. }\end{array}$ \\
\hline  & $\begin{array}{c}\text { Busine } \\
\text { ss \& } \\
\text { Manag } \\
\text { ement } \\
\text { Studies } \\
\text { : An } \\
\text { Interna } \\
\text { tional } \\
\text { Journal }\end{array}$ & $\begin{array}{l}\text { Eskişehir'de } \\
\text { düzenlenen sokak } \\
\text { lezzetleri Festivali } \\
\text { katılımcılarının } \\
\text { festival algıları, } \\
\text { memnuniyetleri, } \\
\text { festivalin algıladıkları } \\
\text { değeri } \\
\text { destinasyona } \\
\text { aidiyetleri arasındaki } \\
\text { ilişkileri araştırmak }\end{array}$ & Korelasyon & $\begin{array}{l}\text { Sokak lezzetleri festivali kapsamında Eskişehir'i ziyaret } \\
\text { ede katılımcıların, festival memnuniyetinin ve festivalin } \\
\text { algılanan değerinin, turistlerin destinasyon aidiyetini } \\
\text { olumlu yönde etkilediğini göstermektedir. Destinasyona } \\
\text { aidiyet geliştirmede festivallerin pozitif etkisi olduğu } \\
\text { söylenebilmektedir. }\end{array}$ \\
\hline 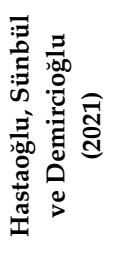 & $\begin{array}{l}\text { Journal } \\
\text { of } \\
\text { Touris } \\
\text { m and } \\
\text { Gastro } \\
\text { nomy } \\
\text { Studies }\end{array}$ & $\begin{array}{l}\text { Sokak lezzetleri } \\
\text { tüketicilerinin } \\
\text { gözünden, bakış } \\
\text { açısını gözlemlemek } \\
\text { ve bilimsel açıdan bir } \\
\text { anlayış geliştirmek }\end{array}$ & $\begin{array}{c}\text { t-testi ve } \\
\text { Anova }\end{array}$ & $\begin{array}{l}\text { Sokak lezzetleri tüketicilerinin, demografik bilgilerinin } \\
\text { sokak lezzetlerine bakış açısı üzerinde anlamlı farklılık } \\
\text { gözlenmiştir. Sokak lezzetleri tercihinde gıda güvenliğinin, } \\
\text { temizliğin önemine dikkat ettiklerini belirtmişlerdir. } \\
\text { Sivas'ta sunulan sokak lezzetlerinin yeterli olmadığ } 1 \\
\text { düşünülmektedir. }\end{array}$ \\
\hline 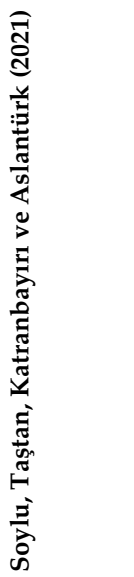 & $\begin{array}{c}\text { Safran } \\
\text { Kültür } \\
\text { ve } \\
\text { Turiz } \\
\text { m } \\
\text { Araştır } \\
\text { maları } \\
\text { Dergisi }\end{array}$ & 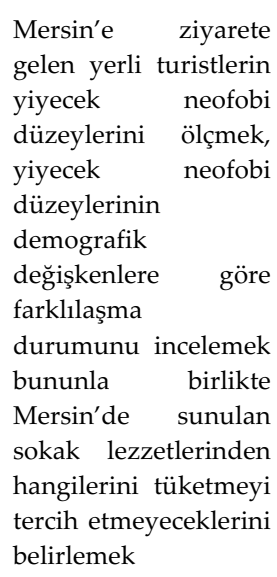 & $\begin{array}{c}\text { t testi, Tek } \\
\text { Yönlü } \\
\text { Anova }\end{array}$ & $\begin{array}{l}\text { Çalışma bulgularına bakıldı̆̆ında, } 266 \text { katılımcının yiyecek } \\
\text { neofobisi konusunda nötr bir tutumda oldukları, } 49 \\
\text { katılımcının da yiyecek neofobisine sahip oldukları } \\
\text { görülmektedir. Katılımcıların yiyecek neofobisinin medeni } \\
\text { durum, yaş, gelir ve meslek değişkenlerine göre anlamlı bir } \\
\text { farklılık göstermediği tespit edilmiştir. }\end{array}$ \\
\hline
\end{tabular}

\section{BULGULAR}

Çalışmanın bu kısmında, araştırma kapsamında anahtar kelimelerle taranan lisansüstü tezlere ve Google Akademikte yer alan makalelerle ilgili ulaşılan verilere ve bu verilerin yorumu yer almaktadır. Bu kapsamda makale türünde 25 çalışmaya rastlanmıştır. Yapılmış tezlere 
bakıldığında 8 lisansüstü tez çalışmasına rastlanmıştır. Bu çalışmalardan ikisinin doktora düzeyinde gerçekleştiği görülmektedir.

Şekil 1. Sokak Lezzetleri Konusuyla İlgili Yayınlananların Yıllara ve Türlerine İlişkin Dağılım

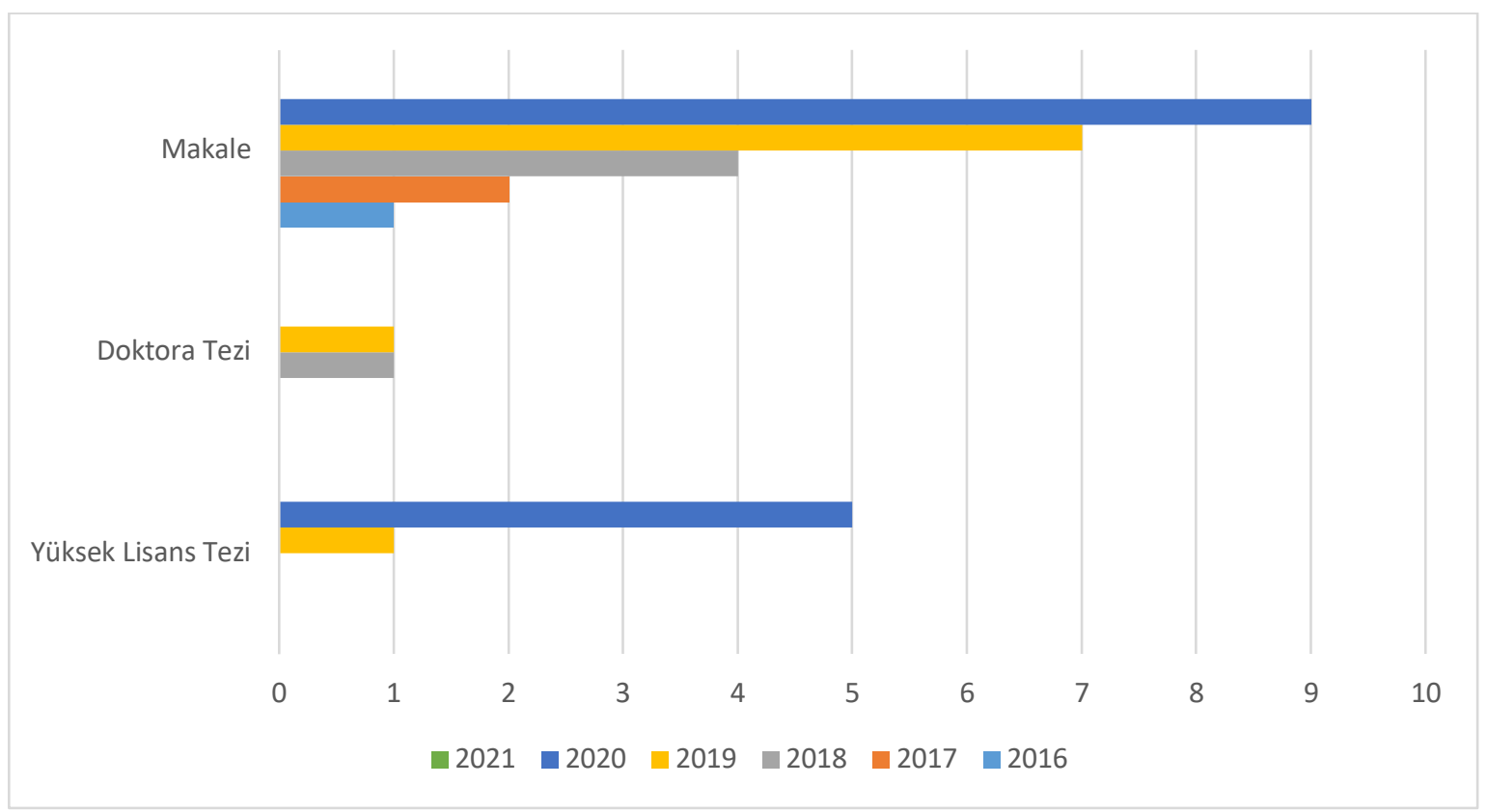

*2021 Yılı için 30 Nisan’a kadar yapılmış çalışmalar değerlendirilmeye alınmıştır.

Sokak lezzetleri konusunda hazırlanmış tezler ve makalelerin hangi yıllarda yayınlandığına ilişkin bilgiler Tablo.3'de gösterilmiştir. Şekil 1'e göre; Türkiye'de sokak lezzetleri ile ilgili çalışmaların daha çok yeni olduğu ve ilk çalışmanın 2016 yılında yayınlanmış olan bir makale olduğu görülmektedir. Türkiye'de sokak lezzetleriyle ilgili ilk doktora tezinin 2018 y1lında, ilk yüksek lisans tezinin ise 2019 yılında yayınlandığı görülmektedir. Sokak lezzetleri konusuyla ilgili çalışmaların 2019 yılında artmaya başlandığı gözlemlenmiştir. Toplamda 2 doktora tezi ve 6 yüksek lisans tezi ile 25 adet makalenin hazırlandığı göze çarpmaktadır. 2021 yılın ilk dört aylık bölümünde ise sokak lezzetleriyle ilgili hazırlanmış bir tez çalışmasına rastlanmamış ancak 2 tane makalenin yayınlanmış olduğu görülmektedir.

Şekil 2. Sokak Lezzetleri Konusuyla İlgili Yapılan Çalışmaların Yazar Sayısı

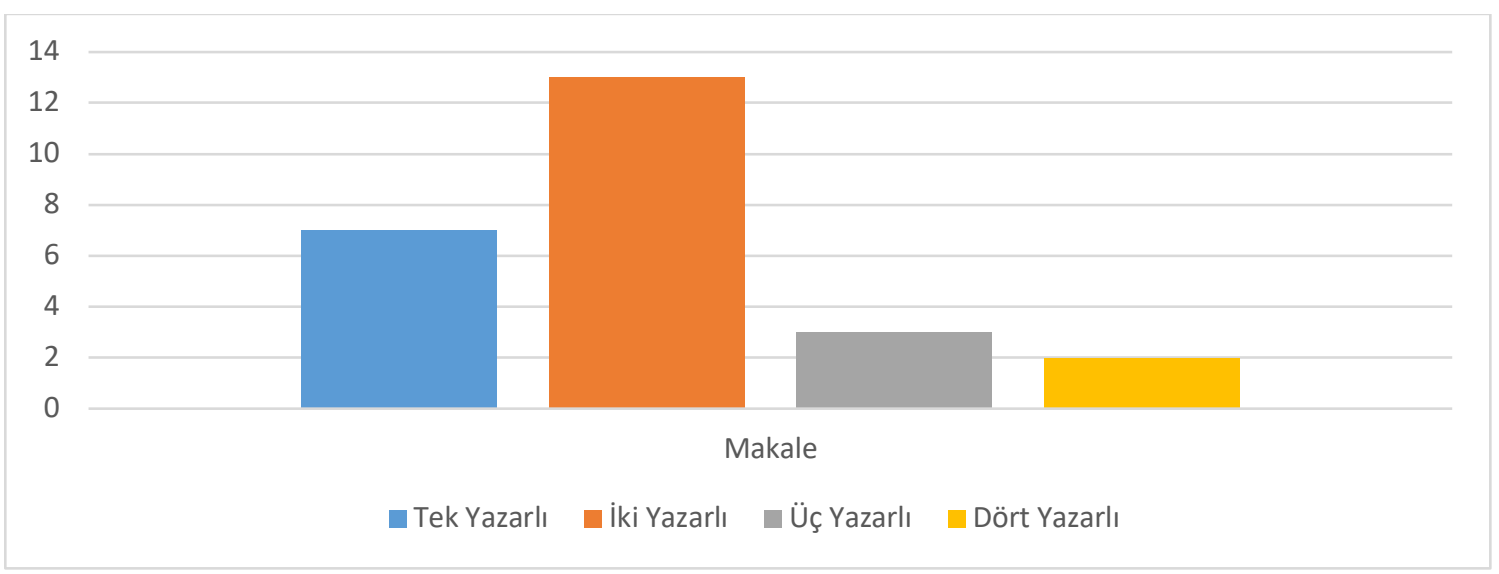


Yapılan çalışmaların yazar sayısı dağılımları Şekil 2'de gösterilmiştir. 25 makale içerisinde 7'si tek yazarlı, 13'ü iki yazarlı, 3'ü üç yazarlı ve 2'si dört yazarlıdır. Çalışmaların yarısından biraz daha fazlasının iki yazarlı olması göze çarpmaktadır. Tek yazarlı çalışmalar, toplam çalışmaların neredeyse dörtte biri kadardır. Buradan hareketle çalışmaların genelinin çok yazarlı olmasında ekip çalışmasının ve lisansüstü öğrenci-danışman çalışmalarından kaynaklandığ 1 söylenebilmektedir.

Şekil 3. Sokak Lezzetleri Konusunda Hazırlanan Lisansüstü Tezlerin A.B.D'na Göre Dağılımı

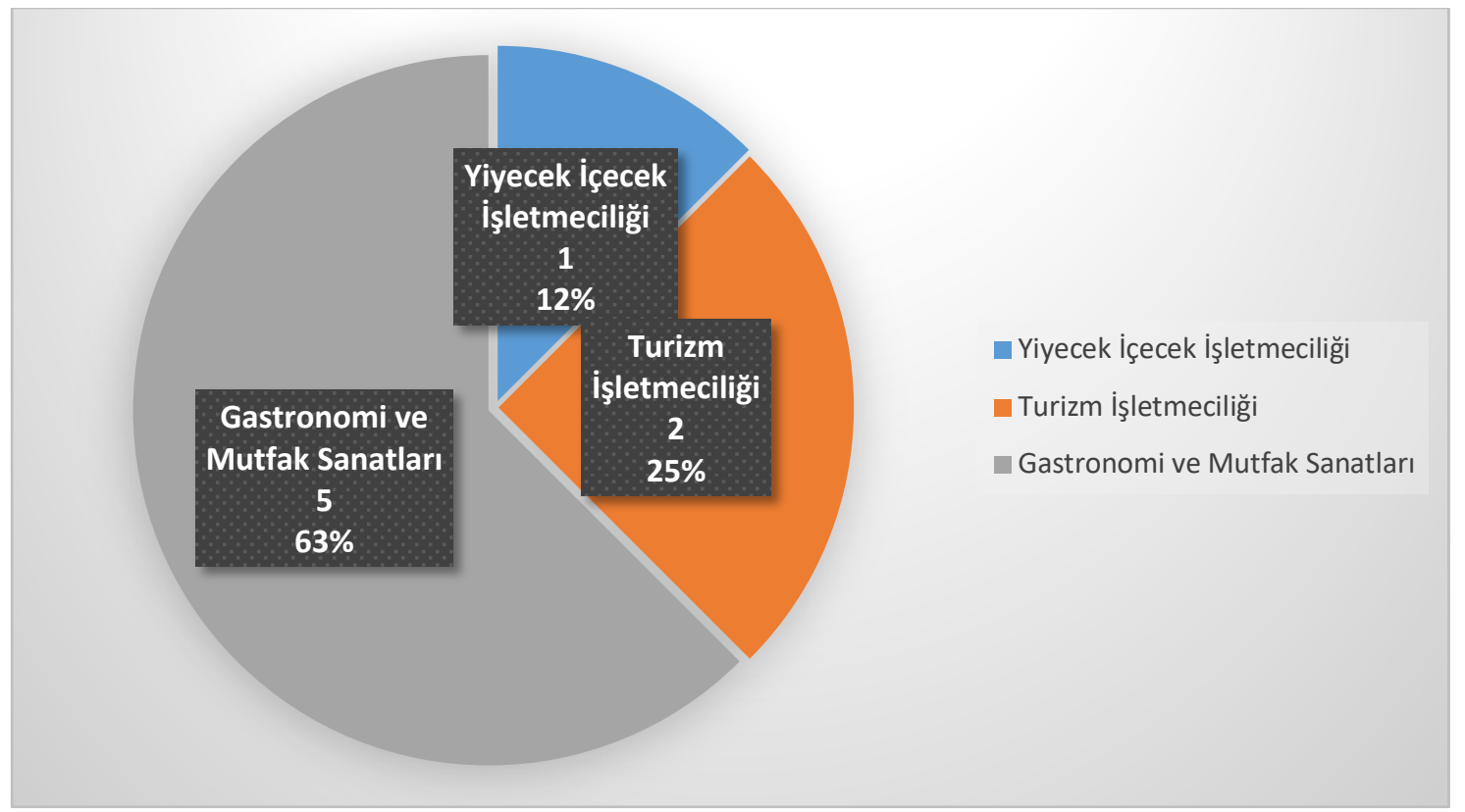

Anabilim dallarına ilişkin Şekil 3'e bakıldığında, çalışmaların üç farklı anabilim dalında yürütüldüğü görülmektedir. Gastronomi ve Mutfak Sanatları, Turizm İşletmeciliği ve Yiyecek İçecek İşletmeciliği lisansüstü tezler hazırlandığı görülmektedir. Yapılan çalışmaların en fazla (5) Gastronomi ve Mutfak Sanatları Anabilim Dalı'nda olduğu göze çarpmaktadır. Sokak Lezzetleri konusu ile ilgili 2016 yılında sadece bir adet lisansüstü çalışma yapılmış iken 2020 yılında bu sayının beşe yükseldiği görülmektedir. Lisansüstü tezlerin, Gastronomi ve Mutfak Sanatları Anabilim Dalı'nda yapılmasının bir nedeni de öğrenciler tarafından çok fazla talep gören anabilim dalının pek çok üniversitede son beş yıl içinde kurulmuş olması gösterilebilir.

Şekil 4. Üniversitelere Göre Yazar Sayısı (Tez)

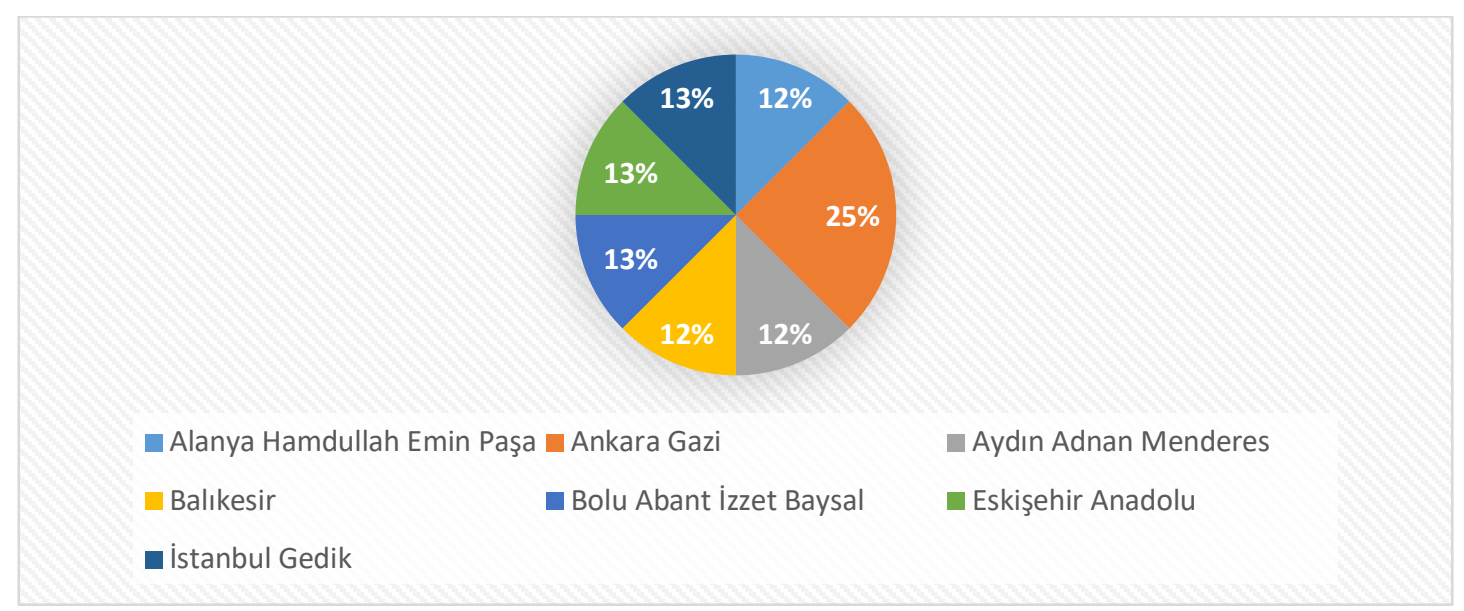


tabanlarında yer alan, sokak lezzetleri ve sokak yemekleri anahtar kelimelerinin yer aldığ1 makalelere başvurulmuştur.

Çalışma ile ulusal alan yazında ilk defa yayınlanmış makalenin 2016 yılında olduğu ve geçen beş yıllık süreç içerisinde toplamda yirmi beş adet makale yayınlandığı görülmektedir. Hazırlanan makale sayısı 2016 yılında 1 iken 2020 yılında 9 adet makalenin hazırlamış olduğu sonucu ortadadır. İlk olarak 2018 yılında tamamlanan ve aradan geçen beş yıllık süreçte toplamda sekiz lisansüstü tezin hazırlandığı sonucu ortaya çıkmaktadır. Doktora tezlerinin yüksek lisans tezlerine kıyasla daha az olması konunun ülkemizde ilk kez 2016 yılında çalışılmaya başlanmasından ve doktora süresinin dört yıl olmasından kaynaklandığı düşünülmektedir. Lisansüstü tezlerinde, farklı bakış açılarıyla konu ile ilgili çalışmaların giderek artacağı düşünülmektedir. Beklendiği üzere sokak lezzetleri-sokak yemekleri kavramlarıla ilgili çalışmaların Gastronomi ve Mutfak Sanatları Anabilim Dalı'nda yoğunlaştı̆̆ı görülmektedir. Bunun nedeninin geçmişte turizmle alakalı lisansüstü eğitimde ağırlıklı olarak turizm işletmeciliği anabilim dalında eğitim veriliyorken artık; gastronomi ve mutfak sanatları, turizm işletmeciliği, turizm rehberliği ve rekreasyon yönetimi alanlarında eğitim verilmektedir.

Kuşkusuz çalışmanın bazı sınırlıkları bulunmaktadır. Lisansüstü tezler şimdiye kadar YÖK veri tabanına girilmiş olanlarla sınırlıdır. Aynı şekilde yayınlanan makalelerde sadece Google Akademikten taranarak ulaşılabilen çalışmalara yer verilmiştir. YÖK veri tabanına henüz yüklenmemiş lisansüstü tezleri ve Google akademikte tarama sonucunda çıkmayan makaleler bu araştırmanın sınırlılığını oluşturmaktadır.

Yükseköğretim Kurulu verilerine göre şu anda Türkiye' de 207 üniversite eğitim öğretim hayatına devam etmektedir. Konu ile ilgili lisansüstü tezlere bakıldığında 7 farklı üniversitede çalışma yürütüldüğü görülmüştür. Bu üniversitelerden 5 tanesi (\%71) devlet üniversitesi iken geriye kalan 2 (\%29) üniversite vakıf üniversitesidir. Yayınlanan makalelere bakıldığında ise, 22 farklı üniversiteden akademisyen ve lisansüstü öğrencilerin çalışma yaptığı görülmektedir. Bunlardan sadece $2(\% 8)$ tanesi vakıf üniversitesi iken diğer 20 tanesi (\%84) devlet üniversitelerinde görev yapmaktadır. Makalelerdeki iki (\%8) yazar bağımsız araştırmacı olarak yer aldığından diğer olarak gösterilmiştir.

Sokak lezzetleri konusu ile ilgili yayınlanmış makaleler incelendiğinde, satın alma niyeti, destinasyon seçimi, gıda güvenliği, yerel halkın algı ve tutumu, destinasyon pazarlaması, gastronomik ürün, gastronomi turizmi, festivaller, sokak gıda satıcıları, tüketici tercihleri, menü içerikleri ve üretimle gibi konularla birlikte ele alındığı görülmektedir. Lisansüstü tezler incelendiğinde ise, tüketici davranışı, gıda güvenliği, tüketici tutumları, destinasyon seçimi, tekrar ziyaret etme niyeti, girişimcilerin formal ve informal eğitim düzeyleri, satın alma niyeti, yazılı medyada sokak lezzetleri konuları işlenmiş̧ir. Araştırmacılar tarafından sayılan bu konularla birlikte işlenen sokak lezzeti kavramı ayrıca incelenen bölgelerin sokak lezzetleri envanterlerinin çıkartılmasına da olanak sağlamıştır. Çalışmalarda o bölgeye ait sokak lezzetlerinden de bahsedildiği görülmektedir.

Makalelerin genelinin gastronomi, gıda, turizm, kültür ve sosyal bilimler alanında faaliyet gösteren dergilerde yayınladığı görülmektedir. Yazarların çalışmanın konusuna uygun dergi seçiminde bulundukları sonucuna ulaşılabilmektedir.

Lisansüstü tezlerin amaçları şu şekildedir: (1) Sokak lezzetlerini tüketme davranışına yönelik tutumun, öznel normun ve algılanan davranışsal kontrolün Planlı Davranış Teorisi kapsamında ele alınarak davranışsal niyet üzerindeki etkisini belirlemek. (2) Sokak lezzetlerine yönelik planlı davranış teorisi bağlamında İstanbul'u ziyaret eden turistlerin tekrar ziyaret niyeti ile destinasyon seçimine yönelik davranışsal niyet üzerindeki etkisini belirlemek. (3) Tüketicilerin algıladıkları hazsal, faydacı değerler ile memnuniyetleri ve davranışsal niyetleri arasındaki 
ilişkiyi açıklamak. (4) Destinasyon tanıtımında ve insan hayatında önemli bir unsur olan sokak lezzetlerinin Türk yazılı medyasındaki (ulusal gazete ve ekleri) yansıması, haberlerin teknik ve gastronomik anlamda ne şekilde ele alındığını incelenmek. (5) Sokak lezzetlerinin tüketiminden kaynaklanabilecek gıda güvenliği riskleri değerlendirilmek. (6) Antalya'da sunulan sokak lezzetlerine yönelik tüketicilerin zihinlerindeki gastronomik imaj ve tutumları incelemek. (7) Sokak lezzetleri girişimcilerinin yaşamış oldukları deneyimler, işletmelerinin mevcut durumu, formal ve informal eğitim düzeyleri ve düzenlenecek olan eğitimlere katılım istekleri hakkındaki görüssleri ortaya koymak. (8) İstanbul'da "Sokak yemeklerinin bilinirlik, beğeni, gastronomik hareketlilik ve gida güvenliği yönünden incelemek.

Nisan 2021 yılına kadar yapılmış olan çalışmalara bakıldığından en fazla yayınların yapıldığı üniversitelerin gastronomi ve mutfak sanatları yüksek lisans ve doktora programlarının olduğu göze çarpmaktadır. Bu üniversitelerdeki bu alanda alışma yoğunluğunun fazla olmasını açıklayan durumlardan birisi de budur. Ayrıca bu konudaki yabancı yayın sayısının fazlalığı da araştırmacıları bu konuda çalışma yapmaya ittiği söylenebilir.

Sokak lezzetleriyle alakalı gelecekte yapılacak çalışmalarda, sokak gıda satıcılarının üniformaları, sokak gıda satılarının kullandığı araç gereçlere, sokak lezzetlerinin restoran menülerinde yer alma durumları araştırabilir. Araştırmacılar, sokak lezzetleri satıcılarının sosyal güvenlik durumları, satış yaptıkları yerlerle ilgili belediye vb. kuruluşa yer ücreti ödeyip ödemedikleri ve vergilendirme ile ilgili konularda çalışma yürütebilirler.

Akademik düzeyde yapılacak çalışmalarla, sokak lezzetlerinin tanıtım ve pazarlamasına, sektör yöneticilerine ve küçük - orta büyüklükte girişimcilere katkı sağlayacak şekilde yapılması büyük önem arz etmektedir. Şimdiye kadar yapılmış çalışmalarda daha çok nicel araştırma yöntemlerinden yararlanıldığı için nitel araştırma yöntemlerinin kullanılacağı çalışmalara yer verilebilir. Ayrıca Michelin yıldızı gibi derecelendirme sistemlerinin dahi sokak lezzetleri satıcıları için kullanılmaya başlanmasıyla birlikte İncili Gastronomi Rehberi ve Yedy gibi derecelendirme sistemlerinde ve platformlarda Türk mutfak kültürüne ait sokak lezzetleri, sokak lezzetleri satıcılarına yer verilebilir. Türkiye turizm tanıtma filmlerinden birinde özellikle sokak lezzetleri ana öğe olarak kullanılabilir.

\section{KAYNAKÇA}

Abiş, A. Z. (2019). Algılanan Değerin Tüketici Davranışlarına Etkisi: Sokak Yemekleri Üzerine Bir Araştırma, Yayımlanmamış Yüksek Lisans Tezi, Aydın Adnan Menderes Üniversitesi Sosyal Bilimler Enstitüsü, Aydın.

Akşit, N. A. (2019). Yerli Turistlerin Sokak Yiyeceklerine Yönelik Tutumlarının Belirlenmesi. Uluslararası Türk Dünyası Turizm Araştırmaları Dergisi, 4(1): 47-61.

Altunbağ, E. (2020). Türkiye'de Yazılı Medyada Sokak Lezzetleri, Yayımlanmamış Yüksek Lisans Tezi, Eskişehir Anadolu Üniversitesi, Eskişehir.

Aydın, B. (2020). Sokak Lezzetlerinin Gıda Güvenliği Açısından Değerlendirilmesi, Yayımlanmamış Yüksek Lisans Tezi, İstanbul Gedik Üniversitesi, İstanbul.

Ballı, E. (2016). Gastronomi Turizmi Açısından Adana Sokak Lezzetleri. Journal of Tourism and Gastronomy Studies, 4(Special Issue 1): 3-17.

Bayraktar, G. ve Zencir, E. (2019). Sokak Satıcılarının Gözünden Sokak Lezzetleri: İzmir Örneği, Journal of Tourism and Gastronomy Studies, 7(2): 1367-1382. 
Bayram, R. (2020). Ziyaretçilerin Sokak Lezzetlerine Yönelik Gastronomik Imaj Algısının Satın Alma Niyetine Etkisi: Antalya Örneği, Yayımlanmamış Yüksek Lisans Tezi, Alanya Hamdullah Emin Paşa Üniversitesi Lisansüstü Eğitim Enstitüsü. Antalya.

Bhowmik, S. K. (2005). Street Vendors in Asia: A Review. Economic and Political Weekly, s.2256-2264.

Cumhur, Ö. (2020). Sokak Gıdalarının Güvenliği İçin Risk Faktörlerinin Değerlendirilmesi, Food and Health, 6(2): 128-139.

Çavuşoğlu, M. ve Çavuşoğlu O. (2018). Gastronomi Turizmi ve Kıbrıs Sokak Lezzetleri Üzerine Bir Araştırma, Güncel Turizm Araştırmaları Dergisi, 2(Ek.1): 637-651.

Demir, Ş., Akdağ, G., Sormaz, Ü. ve Özata, E. (2018). Sokak Lezzetlerinin Gastronomik Değeri: İstanbul Sokak Lezzetleri, Güncel Turizm Araştırmaları Dergisi, 2(Ek.1): 589-601.

Demirci, B., Yılmazdoğan, O. C. ve Düşmezkalender, E. (2020), Festival Alg1sı, Festival Memnuniyeti, Festival Değeri ve Aidiyet İlişkisi: Eskişehir Sokak Lezzetleri Festivali Örneği, Business \& Management Studies, (2020), 8(1): 1096-1112.

Dönmez Polat, D. ve Gezen, A. (2017). Gastronomide Sokak Yiyecekleri ve Satıcıları: Teorik Bir Çalışma, Journal of Tourism and Gastronomy Studies, 5(Special Issue 2): 117-124.

Eren, A. K. (2020). Sokak Lezzetleri Girişimcilerinin Formal ve İnformal Eğitim Düzeylerinin Belirlenmesine Yönelik Nitel Bir Çalışma: İzmir Örneği, Yayımlanmamış Yüksek Lisans Tezi, Balıkesir Üniversitesi, Balıkesir.

FAO, (1986). Regional Workshop on Street Foods in Asia. Jakarta, Indonesia.

Gönülgül, S., ve Durlu Özkaya, F. (2017). Los Angeles ve Toronto Sokak Lezzetlerinin Menü İçeriği ve Üretim Bakımından İncelenmesi, Journal of Tourism and Gastronomy Studies, 5(4): 454465.

Gözgeç, H. ve Aydemir, B. (2019). Gastronomide Kadın Sokak Gıda Satıcıları: Bir Örnek Olay Çalışması, Manas Sosyal Araştırmalar Dergisi, 8 (4): 3854-3870.

Iğdır, E. (2020). Gastronomi Turizmi Kapsamında Sokak Lezzetlerinin Yeri ve Gastronomik Bir Ürün Olarak Değerlendirilmesi. Journal of Tourism Research Institute, 1(2): 101-110.

Kargiglioğlu, Ş. (2019). Planlı Davranış Teorisi Bağlamında Sokak Lezzetlerinin Destinasyon Seçimi ve Tekrar Ziyaret Etme Niyetine Etkisi: İstanbul İli Örneği, Yayımlanmamış Doktora Tezi. Gazi Üniversitesi, Ankara.

Kargiglioğlu, Ş. ve Aksoy, M. (2019). Sokak Lezzetlerini Tatma Amaciyla İstanbul'u Ziyaret Eden Turistlerin İstanbul Seyahatlerinin Değerlendirilmesine Yönelik Bir Araştırma, Journal of Tourism and Gastronomy Studies, 7 (3): 1821-1835.

Kargiglioğlu, Ş. and Aksoy, M. (2020). The Effect of Street Foods on Destination Selection in the Context of Planned Behavior Theory: The Case of Istanbul Province, Journal of Hospitality and Tourism Issues, 2(2), 122- 142.

Karsavuran, Z. (2018). Sokak Yemekleri: Farklı Disiplinlerin Yaklaşımı ve Gastronomi Turizmi Alanında, Journal of Tourism and Gastronomy Studies, 6(1): 246-265.

Kurt, C. O. (2018). Bağımsız Seyahat Eden Turistlerin Sokak Yiyeceklerini Tüketme Niyetinin Planlı Davranış Teorisi Çerçevesinde İncelenmesi: İstanbul'da Bir Çalışma, Yüksek Lisans Tezi, Akdeniz Üniversitesi, Antalya. 
Latifoğlu, A. H. (2020). Sokak Yemeklerinin Bilinirlik, Beğeni, Gastronomik Hareketlilik ve Gida Güvenliği Açısından İncelenmesi, Yayımlanmamış Yüksek Lisans Tezi, Abant İzzet Baysal Üniversitesi, Bolu.

Leong, L.Q., Karim Ab, S.M., Othman, M., Adzahan Mohd, N., and Sridar, R. (2010). Relationships Between Malaysian Food Image, Tourist Satisfaction and Behavioural Intention. World Applied Sciences Journal, 10(10): 164-17.

Oğuz, S. (2020). Sokak Yemeklerinden Yiyecek Bölgelerine-Kentsel Mekânda Gastronomi Hizmetleri ve Mutfak Turizmi: Adana Örneği. Artıbilim Adana Alparslan Türkeş Bilim ve Teknoloji Üniversitesi Sosyal Bilimler Dergisi, 3(2): 1-17.

Oğuz, S. Ballı E. ve Buzcu, Z. (2020). Yerel Halkın Sokak Lezzetlerine Karşı Algıları: Adana Örneği, Turizm Akademik Dergisi, 7(2): 107-121.

Özden, B. (2015). İstanbul Sokak Satıcılarının Kullandıkları Seyyar Araçlar, Food in Life. http://foodinlife.com.tr/makale/670.

Solunoğlu, A. (2018). Sokak Lezzetlerine İlişkin Tüketici Tutumları: Gaziantep ve İstanbul Örnekleri, Yayımlanmamış Doktora Tezi, Gazi Üniversitesi, Ankara.

Solunoğlu, A. ve Nazik, M. H. (2018). Sokak Lezzetlerine İlişkin Tüketici Tercihleri: Gaziantep Örneği, Journal of Tourism and Gastronomy Studies, 6(3): 40-59.

Sünnetçioğlu, S. ve Yıldırım, H. M. (2019). Sokak Yiyeceklerinin Tüketiminde Satıcıya Olan Güven, Algılanan Risk, Algılanan Fayda, Tutum ve Satın Alma Niyeti Arasındaki İlişkilerin İncelenmesi, Manas Sosyal Araştırmalar Dergisi, 8(3): 2799-2818.

Şahin, E., ve Solunoğlu, A. (2019). Planlı Davranış Teorisi Kapsamında Sokak Yemeği Yeme Niyetinin Ölçülmesi: Mersin Örneği, Seyahat ve Otel İşletmeciliği Dergisi, 16(3): 383-397.

Ünal, A. ve İpar, M. S. (2020). Destinasyon Pazarlamasının Bir Bileşeni Olarak Sokak Lezzetlerinin Değerlendirilmesi: İzmir Örneği. Kafkas Üniversitesi Sosyal Bilimler Enstitüsü Dergisi, 13(26), 843863.

Dünya Sağlık Örgütü (WHO). (1996). Essential Safety Requirements for Street-vended Foods. Revised edition, Who/FNU/FOS/96.7. [Erişim Tarihi: 10.03.2021].

Yıldırım, Ö. ve Albayrak, A. (2019). Yabancı Turistlerin İstanbul Sokak Yemeklerini Değerlendirmeleri Üzerine Bir Çalışma, Journal of Tourism and Gastronomy Studies, 7(2): 1077-1092.

Yıldız, E. (2020). Gastronomik Ürün Olarak Sokak Lezzetleri: İzmir Sokak Lezzetleri Üzerine Bir Araştırma. Akademik Sosyal Araştırmalar Dergisi, 8(104): 353-366.

Yiğit, E. A., ve Yiğit, Y. (2019). Gastronomik Ürünler Sokak Lezzetleri. Turan: Stratejik Araştırmalar Merkezi, 11(43): 434-439. 